\title{
IMPLEMENTATION OF THE 2013 CURRICULUM IN MATHEMATICS LEARNING IN CLASS IV AT SDN TALABIU DISTRICTS WOHA, BIMA REGENCY
}

\author{
Nurhoyati \\ STKIP Taman Siswa Bima \\ Email: nurhoyati@stkip.ac.id \\ Ita Fitriati \\ STKIP Taman Siswa Bima \\ Email: itafitriati88@stkip.ac.id \\ Mariamah \\ STKIP Taman Siswa Bima \\ Email: mariamah@stkip.ac.id
}

\begin{abstract}
This research is motivated by the latest regulations on the revised edition 2013 which are new in planning, in which mathematics becomes a self-supplemented subject and is not integrated with other subjects. This type of research is field research (field research) by discussing qualitative, data collection techniques with observation, interviews and documentation, while analyzing the data using the Miles Huberman analysis model, namely: data reduction, data presentation, and verification data. The results of the study show how the teacher steps in compiling the lesson plan that is choosing learning, reviewing the teacher's book, studying the syllabus, then compiling the lesson plan. The RPP prepared by the teacher is in accordance with the concept of the 2013 curriculum. In the implementation of learning in the 2013 curriculum, the teacher has used learning by using scientific learning, and a learning model that is in accordance with the concept of the 2013 curriculum. student knowledge and skills. Authentic assessment used by teachers includes discussion, performance, and written.
\end{abstract}

Keywords: Curriculum, Mathematics Learning.

\begin{abstract}
Abstrak
Penelitian ini dilatarbelakangi oleh peraturan terbaru pada edisi revisi 2013 yang baru dalam perencanaan, di mana matematika menjadi subjek mandiri dan tidak terintegrasi dengan mata pelajaran lain. Jenis penelitian ini adalah penelitian lapangan (field research) dengan membahas kualitatif, teknik pengumpulan data dengan observasi, wawancara dan dokumentasi, sambil menganalisis data menggunakan model analisis Miles Huberman, yaitu: reduksi data, penyajian data, dan verifikasi data. Hasil penelitian menunjukkan bagaimana langkah guru dalam menyusun rencana pelajaran yaitu memilih belajar, meninjau buku guru, mempelajari silabus, kemudian menyusun rencana pelajaran. RPP yang disiapkan oleh guru sesuai dengan konsep kurikulum 2013. Dalam implementasi pembelajaran dalam kurikulum 2013, guru telah menggunakan pembelajaran dengan menggunakan pembelajaran ilmiah, dan model pembelajaran yang sesuai dengan konsep kurikulum 2013. pengetahuan dan keterampilan siswa. Penilaian otentik yang digunakan oleh guru meliputi diskusi, kinerja, dan tulisan.
\end{abstract}

Kata kunci: Kurikulum, Pembelajaran Matematika. 


\section{A. Introduction}

Indonesia has experienced many curriculum changes, including curriculum 1947, 1964, 1968, 1973, 1975, 1984, 1994, 1997, 2004, 2006, and finally 2013. Curriculum changes are often influenced by political factors. For example the 1964 curriculum was compiled to exclude MANIPOL-USDEK, the 1975 curriculum was used to include the Pancasila Moral Education, and the 1984 curriculum was used to include the National History of Struggle Education (PSPB) subjects. The 1994 curriculum, aside from eliminating the PSPB subjects, was also to introduce the high school curriculum which made general education a preparatory education to higher education. During 70 years of Indonesia's independence, it has experienced 12 curriculum changes. The details are during the Old Order era (Orla) or the era of President Soekarno in power, there have been 3 changes to the curriculum, namely (Curriculum) 1947 Lesson Plans, (Curriculum) 1964 Primary School Education Plans and 1968 Primary School Curriculum. Baru (New Order) or the era of President Soeharto's reign, there were 6 curriculum changes, namely the 1973 Pilot School Development Project Curriculum (PPSP) in 1973, the 1975 Primary School Curriculum, 1975 Curriculum, 1984 Curriculum, 1994 Curriculum, and 1994 Curriculum Revision in 1997. After the New Order era ended or the beginning of the reform period, there were 3 changes in the curriculum, namely the 2004 Competency Based Curriculum (KBK), the 2006 Curriculum Unit (KTSP) and the 2013 Curriculum. The curriculum concept develops in line with the development of educational theory and practice, also varies according to the flow or theory adopted. Some experts interpret the curriculum as a plan that provides guidance or guidance in the process of teaching and learning activities. (Loeloek Endah Poerwanti and Sofan Amri, 2013: 3-4). In another definition, the 2013 curriculum is defined as an improvement curriculum of KTSP that is designed with the aim of preparing Indonesian people to have the ability to live as individuals and citizens who are faithful, productive, creative, innovative, and effective, and able to contribute to community, nation, state life and world civilization (Salim Wazdy and Suyitman. 2014: 1).

Inthe 2013 revised curriculum there is something new where mathematics is a subject that stands alone in the semester semester even. This is different from the 2013 curriculum when it was first implemented where mathematics subjects are still integrated or integrated with other subjects. The decision to separate mathematics subjects has many reasons, including content and discussion. For mathematics, on the Integrated Thematic book the depth of the material feels shallow. Therefore students do not get a deep understanding of mathematical concepts. Thus it is necessary to use mathematics books separately. Some of these reasons are the first, mathematics has characteristics of the object of study and methods that are different from other subjects. The object of mathematics study is abstract, the method to carry out mathematics study is deductive, of course by not neglecting the development of $4 \mathrm{C}$ skills (Critical, Creative, Collaborative, and communication). Second, the meaningfulness of learning mathematics in elementary / MI, one of which can be improved through mathematics in the context of the positive world of students. The third meaningfulness of learning is the energy for increasing student motivation, when motivation is already owned learning does not have to be always associated with the real world / theme, the 
reason is mathematics learning with themes has limitations in accommodating the structure and content of magtematics as a whole. Therefore, when the context has been obtained, learning mathematics can be done with a complete understanding of mathematical concepts. Mathematics can be defined as an exact and systematically organized branch of science. Besides mathematics is the science of logical reasoning and problems related to numbers. So that mathematics can be concluded as an organized structure, tools, thinking patterns, ways of reasoning, artificial language, and creative arts (Abdul HalimFathani. 2009: 23-24). So it can be concluded that the 2013 curriculum is a competencybased curriculum that is designed and implemented by an educational institution to achieve educational goals. While the 2013 curriculum in learning mathematics is a curriculum designed and implemented by an educational institution in order to deepen knowledge about logical reasoning to achieve educational goals

After the curriculum development is carried out the next stage is the implementation of the curriculum. Implementation itself can be interpreted as implementation, implementation (Ahmad Maulana, et al). So that the implementation of the curriculum can be interpreted as the implementation of a curriculum that has been designed and assigned to the field or to every educational unit and has been designed a revised 2013 curriculum as a refinement of the previous 2013 curriculum. In preliminary observations and interviews conducted at Talabiu Elementary School in Woha District, Bima Regency, information was obtained from the School Principal that in the implementation of the 2013 curriculum the curriculum was revised where mathematics is a stand-alone subject that is not integrated with other subjects. This is different from the previous year where mathematics was still integrated with other subjects.

\section{B. Research methods}

This type of research is field research with a qualitative approach, namely research that intends to describe how the implementation of the 2013 curriculum in learning mathematics in grade IV SDN Talabiu. The research subjects were teachers and fourth grade students at Talabiu e Elementary School. Data collection techniques using interview, observation and documentation techniques. Analysis of the interview data using stages, namely data reduction, data display, and conclusion drawing / verification.

\section{Research result}

\section{C.1. Planning Mathematics Learning in the 2013}

Curriculum Based on the results of the interview, it was concluded that the steps taken by the teacher in preparing lesson plans in the form of lesson plans were to choose the learning or material to be delivered. learning is already listed in the teacher's book. The teacher's book used is a book provided by the government and in each teacher's book lists the learning sequence, so the teacher chooses the learning to be taught in the order of the learning. The steps taken by the teacher after selecting learning and before reviewing the syllabus and making lesson plans are analyzing SKL, KI, KD, Indicators and examining the mapping of basic competencies and indicators. Another step taken by the teacher in developing lesson plans in the form of lesson plans is to study the syllabus and 
teacher's books. The syllabus used when researchers took data in the field was the Mathematics Syllabus for Grade IV Semester II namely KD 3.10 explaining the relationships between lines (parallel, intersecting, coinciding) using concrete models. The syllabus used by teachers is a syllabus that has been provided by the government. The syllabus from the government used by the teacher contains components such as school identity, core competencies, learning content, basic competencies, subject matter, learning, assessment, time allocation, and learning resources. The following is a detailed explanation of each component. The Mathematics Learning Implementation Plan in the 2013 Curriculum made by the teacher is used for one time learning and is arranged based on the learning material and sub-learning to be taught. The steps taken by the teacher to compile the lesson plan refer to the teacher's book and syllabus. After reviewing the teacher's book and syllabus, then the teacher prepares the lesson plan. The lesson plans are prepared by the teacher and also take the lesson plans on the internet, but they are still adjusted to the conditions of the students. From the teacher's statement, further information was obtained that the lesson plans were prepared by the teacher because they felt they were more effective. Effective here because the teacher can make lesson plans according to class conditions, supply props and adjust the classroom environment as needed during the learning process and also take it on the internet but still be adapted to student conditions. However, if the teacher encounters difficulties in making lesson plans, the teacher will collaborate with other teachers. The teacher prepares the lesson plans themselves and the lesson plans are made before the learning process takes place. The lesson plan is checked and signed by the principal before the teacher implements the lesson plan in learning.

When the lesson plan is checked and signed by the principal, things are found that need to be improved, so the teacher will fix it. Meanwhile, to carry out learning, the teacher is still guided by the RPP except for things that are improved in the RPP. After that the lesson plan was corrected and asked for a signature back to the Principal. Based on the analysis of the Mathematics RPP prepared by the teacher when the researcher retrieves data, components in the 2013 Curriculum RPP include, school identity, class / semester, lesson identity, time allocation, core competencies, basic competencies and indicators of competency achievement, learning objectives formulated based on basic competencies, learning materials, learning methods which are the details of learning activities, learning resource media tools, steps of learning activities, assessment, resources and learning aids.

The next learning step that is described in this lesson plan is the closing activity, in this activity included activities between the teacher and students to reflect on the learning activities that have been carried out, work on evaluation questions by students, collect work results from the beginning to the end of learning by students, action planning and the delivery of learning objectives for the next meeting. Based on the analysis of the RPP the assessment is listed with a detailed explanation starting from the type of assessment, valuation techniques, forms of assessment instruments, and guidelines for scoring. The design of the assessment is written based on the type of assessment (assessment process or results). After that the re-assessment plan is detailed based on the lesson, and its realm (knowledge and skills), for the assessment of attitudes to enter the assessment process and to become one for the entire content of the lesson. 
Based on the analysis of the lesson plan to determine the source in the teacher lesson plan refers to indicators, basic competencies to be achieved and learning material that will be reviewed together with students. Learning resources that are planned to be used include student books, other relevant books, the school environment, and the internet

\section{C.2. Implementation of Mathematics Learning in the 2013 Curriculum}

In the implementation of the 2013 Curriculum, at the beginning of the semester, grade IV teachers received provisions from the School Principal, in the form of socialization of 2013 Curriculum documents. In addition, in the implementation of learning the Teacher was freed by the School Principal to be creative in creating learning in accordance with the learning description of the 2013 Curriculum. in accordance with the description of the 2013 curriculum, the principal seeks the availability of media facilities needed, seeks to provide teacher books and student books, improvement of school facilities and infrastructure, conduct competency trainings such as training competencies using the environment and ICT or ICT for teachers who concerned. In addition, school principals continue to monitor the implementation of the 2013 curriculum, conduct supervision, evaluate the implementation of the 2013 curriculum, and provide assistance and always exchange ideas with the teachers concerned. It is expected that with the provisioning and mentoring in schools, the relevant teachers including mathematics teachers in Class IV will be ready to carry out learning activities in accordance with the contents of learning implementation in the 2013 Curriculum. overview of the implementation of 2013 Curriculum learning. Furthermore, based on the results of observations and interviews, it was found that the implementation of 2013 Curriculum learning carried out by Mathematics Teachers in class IV consisted of 3 main activities namely preliminary activities, core activities, and closing activities. The 2013 curriculum implemented by the teacher consisted of preliminary, core, and closing activities. This is in accordance with the Republic of Indonesia's Minister of Education and Culture Regulation No. 22 of 2016 concerning the standard process in implementing curriculum, which states that the second stage of learning according to the standard process is the implementation of learning which includes preliminary activities, core activities, and closing activities.

Based on the results of observations, in the preliminary activities learning activities undertaken by the Mathematics Teacher, among others, preparing students both psychologically and physically to follow the learning process, asking questions about the material that has been learned or the material to be learned, leading students to a problem or convey an outline of the scope of the material and explain the learning objectives or basic competencies to be achieved, convey activities that students will do to solve problems or assignments, and convey the benefits of learning.

Based on the results of interviews, observations, and documentation obtained data that in the core activities, the implementation of learning that is highlighted by Mathematics Teachers is by presenting the learning process using Curriculum 2013 learning models, and presenting learning using a scientific approach. 
Based on observations, in closing activities the teacher carries out learning activities such as making summaries or summaries of lessons and reflecting on activities that have been carried out, giving written tests, giving feedback on the learning process and results, planning follow-up activities, delivering learning plans at meetings next.

\section{C.3. Learning Assessment in the 2013 Curriculum on Mathematics}

Based on the results of interviews and observations, the teacher mentioned that the teacher used Authentic assessment as a learning assessment approach in the 2013 Curriculum implemented by the teacher. This is in accordance with the Ministry of Education and Culture Republic of Indonesia Regulation No. 23 of 2016 concerning Basic and Secondary Education Assessment Standards that assesses learning outcomes that state that assessment of learning processes uses authentic assessment approaches that assess student readiness, processes, and learning outcomes as a whole. The teacher understands authentic assessment, and the notion of authentic assessment according to the teacher is that the assessment is carried out as a whole, and is continuous, there is no compulsion and really depicts the actual thing assessed by students. During the observation the researcher found that in the 2013 Curriculum learning assessment, the teacher assessed students through 3 competencies, namely attitude competency, knowledge competency, and skill competency. Based on the results of observations, in the assessment of attitude competency the instrument used is a rating scale with rating criteria that are judged as unseen, begin to be seen, begin to develop, and are entrenched. For the assessment of knowledge competencies, based on observations, the teacher assesses students' knowledge competencies using written assessments through written tests, and oral tests. In written assessments, the teacher gives questions from the day's learning. Based on observations, in written assessments the teacher gives questions based on the material being taught and the learning activities that have been carried out. Assessments made by teachers in addition to assessing attitudes and knowledge are skills assessments. Based on the results of observations, one of the assessments used by teachers to assess the competency of student skills is the assessment of performance. However, in the implementation of many aspects of the skills of some of the content of learning that some have not even had time to be assessed by the teacher (using performance assessment). That is because the available learning time is not sufficient for students to carry out the assessed skills and in the end the teacher cannot assess the skills that have not been implemented. In addition to these assessments teachers also often use discussion assessments with assessment instruments used using observation sheets and contain assessment criteria such as listening, non-verbal communication (eye contact, body language, facial expressions, and voice), participation (conveying ideas, feelings of mind) and speech.

Discussion The steps taken by the teacher in planning learning are choosing learning, then reviewing the teacher's book. In studying the teacher's book, the activities carried out by the teacher are analyzing SKL, KI, KD, Indicators. SKL, KI, are already listed in the teacher's book. For KD and indicators are also listed in the teacher's book After that, the learning planning process in the form of the next lesson is to review the syllabus, then make a 
lesson plan. Overall, the lesson plans prepared by teachers have fulfilled the principle that must be considered based on Permendikbud Number 24 of 2016 concerning Curriculum Implementation. The lesson plans are prepared by the teacher themselves because they are more effective if they are made by themselves. Effective here because the teacher can make lesson plans according to class conditions, supply of teaching aids and adjust the classroom environment as needed during the learning process. However, if needed and encountered difficulties while loading the lesson plan, the teacher will collaborate with other teachers or modify the lesson plan taken on the Internet. In addition, before the lesson plan is used first the lesson plan will be examined and signed by the school principal. The lesson plans prepared by the teacher have described the steps of learning and the material with the concept of the Scientific approach, as well as describing the steps of implementing various learning models in accordance with the 2013 Curriculum. In the implementation of the 2013 curriculum in Mathematics, the implementation of learning in the 2013 curriculum was carried out by teachers consisting of preliminary, core, and closing activities. This is in accordance with the revised 2013 curriculum curriculum based on Permendikbud Number 24 of 2016 concerning the Implementation of the 2013 Curriculum which states that the second stage of learning according to the standard process is the implementation of learning which includes preliminary activities, core activities, and closing activities. In the regulation explained in detail that regarding the implementation of learning that reflects the learning of the 2013 Curriculum the activities carried out consisted of preliminary, core, and closing activities.

In the preliminary activities, learning activities undertaken by the teacher, among others, prepare students both psychologically and physically to take part in the learning process through memorizing letters together, reading prayers, and celebrating student news and so forth. The next preliminary activity is the teacher asking questions about the material that has been learned or the material to be learned, then delivering students to a problem and explaining the learning objectives or basic competencies to be achieved, then conveying the activities that students will do to solve problems or assignments. Regarding learning activities in the core activities of the curriculum that in the core activities use methods that are adapted to the characteristics of students and subjects, which include the process of observation, asking questions, gathering information, associations, and communication. Based on these provisions, the teacher has tried to describe the learning process of the 2013 curriculum using a scientific approach consisting of a $5 \mathrm{M}$ learning activity process (observing, asking questions, gathering information, processing information, and communicating) even though the implementation is not done sequentially but is still carried out. In the implementation of learning, the teacher always tries to meet the requirements of implementing learning in accordance with the 2013 Curriculum, such as always using the lesson plan at each meeting, allocating face-to-face hours for each learning load for 35 minutes, providing student books even though in reality the availability of Mathematics books for students, especially the most recent revisions, is still less, then the teacher also, seeks to provide media, tools and learning resources to support student learning activities, by providing it themselves, borrowing from school, the teacher also directs students to prepare the tools and materials needed, other requirements for implementing learning 
are the teachers adjusting the seating arrangements of students in accordance with the objectives and characteristics of the learning process by forming student seating into groups. Groups are sometimes made into large groups or small groups. Seating positions are arranged in groups also move around. The seating arrangement in groups begins to be determined by the teacher every Monday before each week the seating arrangement changes whether it changes its layout or students' seatmates, it is done by the teacher to train students to get along and work with others.

In carrying out learning, the teacher also pays attention to the volume and tone of voice. In the learning process, the volume and intonation of the teacher's voice is quite loud. The teacher is obliged to use polite words, straightforward and easy to understand by students, adjusting the subject matter with the speed and learning ability of students. The teacher creates order, discipline, comfort, and safety, provides reinforcement and feedback on students' responses and learning outcomes during the learning process, encourages and values students to ask and express opinions and dress modestly, cleanly, and neatly. The teacher starts and ends the learning process according to the scheduled time. Teachers always try to meet these requirements, although in their implementation meeting the requirements of the implementation of 2013 Curriculum learning many obstacles, but teachers always try to overcome these obstacles. Based on the results of the study, it can be concluded that teachers use authentic assessment as a learning assessment approach in the 2013 Curriculum. This is in accordance with the Ministry of Education and Culture Republic of Indonesia Regulation No. 23 of 2016 Concerning Basic and Secondary Education Process Standards. Assessment of learning outcomes and processes which state that assessment of learning processes uses authentic assessment approaches that assess student readiness, processes, and learning outcomes as a whole.

In the 2013 Curriculum learning assessment, teachers assess student learning processes and outcomes through 3 competencies namely attitude competencies, knowledge competencies, and skills competencies. Furthermore, the results of the study show that the teacher's initial reference in making the design and learning assessment criteria is to look at the syllabus, BC and Indicators. This is in accordance with Permendikbud No. 66 of 2013 concerning Assessment Standards (2013: 6-7) which states that the assessment process begins with reviewing the syllabus as a reference in making the design and assessment criteria at the beginning of the semester. In addition to paying attention to the syllabus, teachers also pay attention to basic competencies and indicators. Based on the $\mathrm{BC}$ and indicators examined, the teacher can then determine the type, technique, assessment instrument, and scoring guidelines. Furthermore, the results of the study explained that the stages of the implementation of Assessment in learning are observing students then assessing students per aspect but for Mathematics subjects the teacher only focuses on assessment of aspects, knowledge only and to assess these aspects the teacher uses various kinds of assessments. For the assessment of Knowledge Competence, based on observations, the Teacher assesses students' knowledge competency using written assessments. through written tests and oral tests with questions from the learning content. This is in accordance with information in Permendikbud No. 66 of 2013 concerning Assessment Standards (2013: 4) which explains that in written assessments through Educators assess knowledge competency through written 
tests and oral tests. In this Permendikbud also explained that the written test instrument in the form of multiple choice questions, fields, short answers, etc. The description instrument is equipped with scoring guidelines. In addition to written tests, to assess aspects of teacher knowledge also uses oral tests with an instrument in the form of a list of questions that must be answered by students.

\section{Conclusion}

Based on research conducted at Talabiu Elementary School in the implementation of the 2013 curriculum for learning mathematics, that in its implementation was in accordance with the revised 2013 curriculum guided by Permendikbud number 24 of 2016 article 1 paragraph 3.

\section{Bibliography}

Abdul Halim Fathani. (2013). Mathematics Itself and Logic, Yogyakarta: Ar-Ruzz Media

Ahmad Maulana. DKK, Complete Popular Scientific Dictionary, Yogyakarta: Absolute

Abidin, Jonah. (2014). Learning System Design in the Context of Curriculum 2013, Bandung: PT Refika Aditama

Deddy Mulyana. (2004). Qualitative Research Methodology, Bandung: PT Youth Rosdakarya

E.Mulyasa. (2013). Curriculum Development and Implementation 2013, Bandung: PT Remaja Rosdakarya Ministry of Education and Culture, (2013). Development and Implementation of 2013 Elementary Curriculum Loeloek Endah Purwanti and Sofan

Amri. (2013). Guide to Understanding the 2013 Curriculum, Jakarta: Librarian Achievement. Nana Syaodih Sukmadinata. (2010). Educational Research Methods, Bandung: Rosdakarya

Offset __ (2009). Theory and Practice Curriculum Development, Bandung: PT Youth Rosdakarya Offset

Oemar Hamalik. (2009). Basics of Curriculum Development, Bandung: PT Youth Rosdakarya

Permendikbud (2013). Basic Education Process Standards Permendikbud (2016). Curriculum Development Guide 2013

Salim Wazdi and Suyitman. (2014). Understanding the 2013 Curriculum Practical Guide for Teachers of Basic Mathematics Education, Yogyakarta: Terrace

Sugiyono (2011). Educational Research Methods (Qualitative Approach), Bandung: Alfabeta

Suharsimi Arikunto. (2010). Procedure for Study of a Practical Approach, Jakarta: Rineka Cipta 